\title{
Promoting Active Learning for Increasing Students' Understanding of the Teaching Materials: A Report on Teaching Experience in Computer Science
}

\author{
M Sulistyoningsih*1 \\ Universitas Atma Jaya Yogyakarta \\ E-mail: margaretha.teaching@gmail.com
}

Submitted: 18 August 2020, revised: 21 August 2020, accepted: 23 August 2020

\begin{abstract}
Abstrak. Proses belajar-mengajar memiliki tujuan agar semua peserta didik memahami materi yang diajarkan di kelas. Namun dalam proses belajar-mengajar, sering masih terjadi kesenjangan pemahaman antara peserta didik yang sangat memahami materi ajar dan yang kurang/tidak memahaminya. Hal ini menyebabkan tujuan pembelajaran tidak dapat tercapai sepenuhnya bagi seluruh peserta didik. Pembelajaran aktif (active learning) dapat menjadi salah satu jalan keluar yang memungkinkan untuk dilakukan, untuk memecahkan masalah tersebut di atas. Penelitian menunjukkan bahwa pembelajaran aktif meningkatkan prestasi belajar peserta didik. Hal ini juga berlaku untuk pendidikan di universitas. Transfer pengetahuan antar mahasiswa dapat dilakukan dalam pembelajaran aktif di kelas. Diskusi kelompok menjadi hal yang penting dalam pembelajaran aktif. Kami telah menerapkan pembelajaran aktif di kelas-kelas kami, di mana mahasiswa juga diajak untuk mengajar dalam kelompok kecil atau di depan kelas. Artikel ini menceritakan pengalaman kami dalam merancang dan menerapkan strategi pembelajaran aktif di kelas. Setelah melihat keberhasilan mahasiswa di akhir semester, kami ingin mendapatkan masukan dari mahasiswa tentang dampak positif pembelajaran aktif terhadap pemahaman mereka mengenai materi ajar. Studi kami lakukan dengan meminta mahasiswa mengisi kuesioner secara anonim di Google Form. Tiga puluh enam mahasiswa mengisi kuesioner tersebut. Lebih dari $93 \%$ jawaban yang diberikan menunjukkan bahwa perancangan kelas yang menerapkan pembelajaran aktif mempengaruhi secara positif pemahaman mahasiswa terhadap materi ajar. Mahasiswa juga memberikan respon positif dari personalisasi pembelajaran yang kami berikan selama aktivitas kelompok-kelompok kecil berlangsung di kelas. Kami menyimpulkan bahwa desain kelas yang menggabungkan pembelajaran aktif bermanfaat bagi peningkatan pemahaman mahasiswa terhadap materi ajar.
\end{abstract}

Kata kunci: pembelajaran aktif; student centered learning; pembelajaran ilmu komputer; pembelajaran sistem informasi; pendidikan tinggi

Abstract. Knowledge gap among students is one of the challenges in teaching-learning process. Active learning can be one possible way to the solution, as study shows that active learning increase students' achievement. Knowledge transfer between peers can have its place in an active class, since group discussion is part of the class design. We have been applying active learning in our classes where students were invited to teach in small groups or in class. In this paper we share about our experience in designing and implementing active learning strategies in our classes. After witnessing students' success through active learning, we conducted a study to gain students feedbacks about the positive impacts of the active learning 
to their understanding of the teaching material. Thirty-six students fill out the questionnaire in Google Form anonymously. The result shows that our class settings that employ active learning increases students' understanding of the teaching materials and hence, students' grade. Over $93 \%$ give positive feedback about our class design and implementation. Students also give positive feedback about our personalized teaching and personal approach during the group activity in our classes. We conclude that class designs which incorporate active learning, is beneficial for students to increase their understanding of the teaching materials.

Keywords: active learning; student centered learning; computer science education; information systems education; higher education

\section{Introduction}

In the teaching-learning process, each student has equal right for the academic takeaway. It is indeed the goal of every instructor to gain all students' maximum understanding about the teaching materials. However, it is not unusual that by the end of a topic, students have different levels of understanding about what had been taught. Problems worsen when the past topic is the foundation of the next ones. Students without full understanding of the previous topic would have problems for following the next. Another problem rise when there is a big gap among students that gain the highest and the lowest understanding of the past subjects.

Since those problems mentioned above are very common, instructor can take action from the beginning of the semester to prevent those problems to arise later in class. A class design that incorporates active learning can be one possible way to the solution. Definition of active learning is a student-centered learning where students participate actively in the teaching-learning process. Students are allowed to teach, to lead the group or class discussion. "Learning by doing" principle is applied where students, with their peers in small groups working on exercises for solving problems during the class meetings, and present their result to the class. Problem based learning and projectbased learning has its place in an active class.

It has been known that active learning has contribution in raising students' grade [2][3][6]. As opposed to Teacher Centered Learning, active learning has many other good values that lead not only to students' involvement in the teaching-learning process, but also to teamwork, and managerial [1][2]. Based on our experience, active learning leads to knowledge transfer between peers in the small groups or in class. When students are active in class, their neurons (the brain cells) are also active to make and to strengthen the connections, so called synapses. Strong synapses lead to smooth transportations of information between neurons, which enable students to retain memories [6], in this case, memory that is related to the subject being discussed in class and the connection and analogy with past knowledge.

We have been applying Active Learning in our classes. Some strategies were used in designing the classes, e.g., dividing class into small groups for smoothening students' discussion, and inviting students to teach and to lead discussion in-group or in class. Some strategies are taken for preparing students for this innovative class design, namely, by words explaining to the students about the importance of collaboration with different kind of people for Computer Science (CS) students, since CS can be applied in various aspects of life. Other strategy is to help students constructing selfefficacy by giving small chunks of exercises with ascending level of difficulties. We believe that students who have succeeded in the first exercise will have more confidence to work on next chunks of exercise with higher level of difficulties. Students with self-efficacy tend to be active in class. Being active in class leads to gaining good grades [2][3][6], and having good grades lead to selfefficacy. This is the positive chain reaction we aim to have in our classes.

Personalized teaching is also important since some students may have different pace in learning, or need to be given more examples in order to understand the teaching materials. Knowing students name, and knowing their pace and learning style is important. Students need to know that they are all 
respected and welcome to the class activities. That can make them comfortable in the active class environment and finally, to ease them in perceiving the teaching materials. In section 3 we explains our strategies for incorporating personalized learning in our classes. Personal approach to the students groups during the class activity is also important. Since we incorporate teaching-learning process between peers, we need to ensure that all students construct the right knowledge.

In this paper we share our experiences in designing and implementing active learning in our classes. After witnessing students' positive progress in our classroom environment that incorporates active learning, we aim at having systematic feedback from students. After the semester ends, students were asked to fill out a questionnaire anonymously in Google Form. Qualitative Research was done for examining students' responses on the questions related to active learning.

The results showed that $93.02 \%$ of student responders give positive response about our active class design. Active learning in class has helped students to gain better understanding of the teaching material. Small group discussion and peer teaching are indeed beneficial for the students. Personalized teaching is still needed to help students understanding the teaching material, and as supervision from instructor so that the students are on the right track, i.e., constructing the right knowledge. Since class design presented in this study is a generic design, it can be applied into other study program such as, Information Systems, Engineering Study program, or even non-engineering study program.

This article is constructed as follows: After this Introduction, theories of educational psychology, pedagogy and neuroscience that are related to teaching-learning experience, is presented in section two. Section three tells about our class design and our teaching methods. The beginning of explanation about our research where we aim at gaining students' feedback about our teaching methods is presented in section four. Section five presents the research result and the discussion of it, followed by conclusion in section six.

\section{Theories and Related Works}

Dahlgreen[2] reports that active learning increases students' score by $6 \%$. Working to solve problem in a small group of 5-7 students makes students learn to formulate and to verbalize their ideas of the possible solution to their peers. Freeman, et.al [3] reports that students' score is increased by 6\% in active learning, among Science, Technology and Math (STEM) students. Students in the class of traditional teaching are 1.5 times more likely to fail. In the definition of "active learning", Freeman [3] mentioned that active learning involves group work. Collaboration makes students more involved in the learning process [9].

Self-efficacy is also important to support students' active learning. Komarraju and Nadler [5] discussed about self-efficacy that leads to higher level of academic achievement. Self-efficacy is theory of A. Bandura that states that self-efficacy is ones' self-confidence on their capability to produce expected performance. Self-efficacy is formed through life experiences $[12,14]$. Wilde and Hsu [10] reports that students with low self-efficacy tends to make negative comparison that can lead to hindering of gaining higher self-efficacy. In the contrary, students with high self-efficacy tend to ignore the negative information so that they can concentrate to finish the task at hands. Zientek et.al., reports that there is a positive implication to self-efficacy from curriculum that emphasize collaboration. Ozkal [13] reports that self-efficacy in Math was constructed through experience of positive achievements and positive feeling. Therefore, they suggest that teacher should design the class so that students experience positive achievements. This is aligned with Bandura's theory [12, 14]. Aylion, et.al. [15] reports that teacher's involvement and students' self-efficacy have positive correlation to student's achievements. Turner, et.al. [16] reports that self-category impacts students' outcome.

Owens and Tanner in [6] discussed about the benefit of think-pair-share that change the students' brain in positive ways during the process of: Think individually to solve problem, pair with peers, in this case with the group members, for discussing the solution, and share their ideas and 
thoughts about the solution to a larger group, in this case, to the class. Besides that, it is essential to prepare students to work in teams since collaboration is needed in almost all work-settings [4].

Owens and Tanner [6] also discussed about synaptic plasticity, which is the process of changing in the number of connections between neurons, and the strengthening of the connections during learning. Frequently used connections are enhanced the most. Woolfson [7] also discussed the same theory that synapses (the connection between neurons) that are used frequently and repeatedly are being strengthened, while those that are rarely used are prone to pruning. Emphasizing the finding above, Owens and Tanner [6] also discussed that students' activity in pair and share boost the encoding of memory in synaptic connections and neural circuits.

Cooper, et.al. [17] mention that perceiving that their name is known by their instructor makes students feel comfortable to seek help from their instructor about the issue they face in the class or even talking about topics outside the teaching materials. The fact that students feel comfortable to seek help from their instructors, have positive impacts in their chance to be succeeded in class. Students in their study also speak out that the fact that their instructor knows their name makes them feel that they are not only the face in the crowd, but makes them feel that their instructor knows them in a personal level. Tanner [18] mention that knowing and calling students by their name can increase the sense of welcoming, promote inclusivity and equity in the classroom.

\section{Our Experience in Implementing Active Learning Class}

In this section we present our active classes design where students are not only passive listeners, but also active participants during the class meetings. We present some of our experiences as well, to give examples about the implementation of the strategies.

\subsection{Dividing class into small groups of students}

On the first day of the class meetings, small groups of students are formed. This group is valid for the whole semester. This means that students in the same group should work together for group-graded quizzes, projects and presentation. The members of the group are chosen randomly. Before doing so, we need to explain the reason behind the randomized grouping; since many students are afraid that randomized grouping might impact their grades. Students are usually worried about working on assignments and projects for the whole semester with the group members that are considered as "notso-smart" or "not-so-diligent" peers, or with peers they are not comfortable with.

To prepare the students for randomized grouping we explain that Computer Science (CS) students need to learn to collaborate with all different kinds of people, since CS can be applied in almost all aspects of life. Later, in the work place, CS graduates can face situation where they cannot choose the people they work with, or the people who will be their clients. Students need to be told that in class, learning and practicing collaboration with any kind of peers in solving problems, is as crucial as learning new technology or methodology. They will surely benefit from these valuable lessons from collaborating. This preliminary teaching can bring students into an understanding that each of them need to focus on how to work together to solve problems at hands rather than to focus on who they are working with.

After the explanation about the importance of the randomized grouping, small groups are formed. Usually, in the first day, students tend to sit close to their peers that are "similar" to them, or to the peers they know well. Knowledge gap would be last until the end of the semester since the "smart" students will sit down and work together. Students would not learn how to collaborate with, so called, their "outsider". The way we form the randomized grouping is that each student was asked to speak out one number respectively, row-wise. The number to be spoken out is between 1 to the number of the intended group. For instance, if we are intended to build 5 small groups in the class, we ask students to speak out one number between " 1 " to " 5 " sequentially, row wise. Students that spoke out number "1" are the members of group number " 1 ", and so forth. 


\subsection{Constructing students' self-efficacy}

In an active class design that involves small groups activities, it is very crucial that students are comfortable with selves and with each other so that they can contribute optimally to their group, and hence, to the class. Positive feeling of having contributed to the group or to the class brings selfefficacy. And vice versa, students with self-efficacy will be confident to contribute to the class. Positive chain reaction will be constructed here.

Contribution of group members related to the way students see themselves. Some students see themselves as a smart student; some see themselves as ordinary, and some see themselves as slow, not smart enough, and does not have what it takes to succeed. Students of the first type, i.e., students with high self-efficacy, usually lead the discussion in the group. They are active and responding fast to the tasks that are being given. They are fully aware that the group grades are their grades, so that as high achievers, they will be trying to solve the whole problem by themselves first. If group representations are asked to present group discussion result in the class forum, the first type of students will be the first on stage.

Students with low self-efficacy tend to create distance with their peers. Some students even see themselves as a burden to the group. Feeling uncomfortable with self and with peers can lead to less willingness for contributing to the group and to the class activity. Being not fully engaged in the class activity will lead to partial comprehension of what is being taught in the class. Therefore, inclusivity in each group that contains students with high and low self-efficacy is of critical importance to be promoted since the first day of the class meetings.

We have class designs to gain students self-efficacy. Modular teaching can help raising students' self-efficacy, as explained in section 3.3. Another strategy is a gentle intervention from the instructor to the group. Students who have not fully understood the teaching material usually have low selfefficacy. If there was another student in the group that has fully understood the teaching material, he/she can be asked to teach his/her group fellow who has difficulty in completing the task. When the teaching-learning process between peers is finished, the student who just learned from his peer is asked to represent the group to work on the exercise in front of the classroom, accompanied by the student who mentored him. Bonus point is given for the group work as an immediate reward after they finish the task. That way, the student who just learned from his peer would gain more selfefficacy, as he/she was able to understand the teaching material, and even contributed some points to his/her group. The student who mentored his peers also gains more self-efficacy, as he/she was succeeded in teaching his/her fellow peer in the group.

\subsection{Modular methods of teaching}

Teaching materials are divided into small chunks and in its section, there is exercise to be presented to students for a group discussion. The goal of this approach is to gain students' maximum understanding of the subjects being taught, and to build student self-efficacy.

Understanding the first small part of the teaching material constructs students' self-efficacy for working on the next small chunks of exercises that might be more complex than the previous one. There are also bonus points for being active in the class, as a reward for doing those exercises and presenting the result to the group or class. The reward should help constructing students' self-efficacy as well.

\subsection{Students are invited to teach}

By comprehending the importance of think-pair-share Owen [6] as discussed in section 2, we invite students to teach in their group or in front of the class. For the students who gain the full understanding of the topic, we suggest them to share their knowledge to their peers. As mentioned in section 2, according to Neuroscience, the more one teach, the more he himself/she herself become smarter [6]. To the students with low academic performances (at that time), hence low self-efficacy 
and self-esteem, we make personal approach so that they do not hesitate in asking to their peer or to us, the instructor, about the subject that has not been clear for them. Successfulness of teaching learning between peers was measured by asking the students that has been taught by their peer to present the result of their work or to show it by working on the exercise on board accompanied by their peer who taught them. This is also part of supervising the active learning process, explained in section 3.6.

As the students' discussions in small groups sustained, understanding of new practical skill will be propelled as the group members are helping each other and strengthening each other's capability. An experience from a Pattern Recognition class, we give assignment to make software for automatic classification of ripe and unripe tomatoes that can be used in the tomato sauce or tomato juice factory. We asked students to use GNU Octave, an open source language and tools that primarily for numerical computation.

Two phases of the software should be made, namely Training Phase and Testing Phase. We make lab module that contains only some important instructions for the Training Phase and let the students using their own creativity to write the entire phase in a complete program. While for Testing Phase, students were required to write the program from scratch. Some students were able to follow the module, while the other ones have variety of problems. Students helped each other, and in the next meeting, more than $90 \%$ of students finished in writing the program, and on the way to finish the report.

Before teaching-learning process between peers are begun, students need to know that both student that teach or learn from their peers, has mutual benefit from the activity. According to Neuroscience, as explained in section 2, Owen and Tanner [6] reports that student will gain more understanding of the teaching material by teaching and sharing the knowledge to their peers. Some of our experiences in employing teaching-learning process between peers in small groups of students are explained as well in the next session, as this takes part of personal approach of the instructor to the group.

\subsection{Personalized teaching and assessment method}

Another advantage of dividing class into small groups is that it is easier for us to know and to remember students name and their progress; since presentation of students were in small groups, rather than presentation of the whole class at once. We believe that students push themselves to study harder when their name are known by the instructor. Knowing students name makes it easier for us to know which students are active, which students are having rapid progress, and which students are at risk. By knowing so, we can personalize our teaching method for the students to increase their probability of being success.

Personalized teaching is carried out daily in the classroom by visiting the groups while they are working on exercises for solving problems. Some students hesitate to ask in public, so that when the instructor visits them, they would ask personally. We normally do not need to visit all groups. Gesture and facial expression of students who has difficulties on finishing the task at hand might be different from those who know exactly what to do. We need to pay attention and look around the class to decide which group to be visited first. Some students might need explanation from the beginning, some might need only part of the topic of that day, and some might have only a little misunderstanding. Students who have full understanding of the topic and finishing the exercise are asked, by their willingness, to explain the topic to their fellow in the same group. Later we will come back to check on them, to make sure that they construct the right knowledge. By doing so, we as instructor will have more time to reach students that need more of our attention and time. Students can also come to our office hour asking about certain topic that has not clear for them.

Through our experience, students need to know that they are with their own pace in studying are respected in our classes. There are no stupid questions. All questions are important, since their fellows 
in the class might have the same question, and would be thankful when they asked the question. We encouraged them not to be afraid to give wrong answers for the questions/problems that are being discussed. By knowing their name, and knowing that they are respected, students will be more comfortable to the active class environment.

Personalized assessments are done in our classes well, since students can have very high capability in one aspect, but not so high in another. For instance, in the Capita Selecta Medical Image Processing and Visualization class, there are some students who were excelling in Image Visualization section. They have passion in programming so that they develop the prototype for medical image visualization. They even lead the class discussion for the image visualization. For those active engagements, they gain bonus points. By having those rewards, students will know that his/her passion was respected. That can lead to pilling up self-efficacy throughout the process.

\subsection{Supervising the active class}

It is crucial for an active class to be supervised by the instructor. There is a danger when students construct their knowledge from their peer without instructor's supervision. Instructor should ensure that all students are on the right track. Hartikainen, et.al in [8] mentioned that active learning does not mean that students do on their own without supervision of their lecturer, and construct knowledge from any source.

From our experience, instructor's visit to the small groups during the group exercise was of critical importance. It can prevent false teaching between group members that has not fully understood the theory or the instruction. Examining students' works and give group personal teaching is not harmful for the whole process of active learning, especially when there is a misunderstanding about the crucial points of the teaching material. Individual quiz (not a group quiz) can be held in the end of the class meeting to measure students' understanding individually.

\section{Research Data and Methodology}

After witnessing students' positive progress in our classes that embodying active learning, we aimed at gaining students' feedback trough a systematic research. The goal of the research is to answer the question whether or not our active learning class design has help students to understand the teaching material, hence to help students gaining good grades.

In November 2019, we asked students that have taken our classes in the previous semesters to fill out the questionnaire on Google form, anonymously. The links of the Google form were announced through WhatsApp group of our previous classes. Thirty-six students fill out the questionnaire for our classes they took in the previous semesters.

Research methodology that is used in this study is qualitative research methodology. Questions and answers that were related to active learning and its impact to students understanding of the course material can be seen in table 1. Answers were open ended, so that students can give reason after answering "Yes" or "No".

\section{Results and Discussion}

Questions and students' answers can be seen in Table 1. The questions and students' answers were in Bahasa Indonesia. Since the answers were open-ended, we need to categorize them manually after the questionnaire was filled. After examining students answer, we come with categorization of students' answer as seen in table 1, i.e., "Very much", "Yes", "Fair", and "No". Table 2 shows how in this study, students' answers were categorized. When students' answer contains the words (in Bahasa Indonesia) "sangat", "sekali", "amat" which means "very much", the category of the answer is "Very much", and so on. Full mapping of the keyword in Bahasa Indonesia and the category can be seen in Table 2. 
Table 1. Questions and students' answers

\begin{tabular}{|c|c|c|c|c|c|}
\hline \multirow[b]{2}{*}{ No } & \multirow[b]{2}{*}{ Questions } & \multicolumn{4}{|c|}{ Students' Answers } \\
\hline & & $\begin{array}{l}\text { Very } \\
\text { much }\end{array}$ & Yes & Fair & No \\
\hline 1. & $\begin{array}{l}\text { In the class, I always gave students small exercises to } \\
\text { be done together with the group members. } \\
\text { Did those exercises help you to understand the } \\
\text { teaching materials? }\end{array}$ & 12 & 24 & 0 & 0 \\
\hline 2. & $\begin{array}{l}\text { In each class meeting there were bonus points as } \\
\text { rewards for those who were active in the class. } \\
\text { Did those points motivate you for being active in } \\
\text { class? }\end{array}$ & 3 & 28 & 3 & 2 \\
\hline 3. *) & $\begin{array}{l}\text { The goal for asking students to work on the exercises } \\
\text { on the board was to help students understand the } \\
\text { teaching materials. } \\
\text { Have you ever been asked to represent your group to } \\
\text { come forward and working on an exercise on the } \\
\text { board? Did that make you understand the teaching } \\
\text { material better? }\end{array}$ & 9 & 25 & 0 & 1 \\
\hline 4. & $\begin{array}{l}\text { In some occasions, I tried to motivate students using } \\
\text { stories or positive words. } \\
\text { Did that have a good impact to you? }\end{array}$ & 10 & 22 & 2 & 2 \\
\hline 5. & $\begin{array}{l}\text { When students work on exercises in class, I often } \\
\text { walked around the class to visit the small groups and } \\
\text { explained the teaching material to students that has } \\
\text { not fully understood it. } \\
\text { Did that help you to understand the teaching material } \\
\text { better? }\end{array}$ & 14 & 21 & 1 & 0 \\
\hline 6. & $\begin{array}{l}\text { I always tried to remember students' name. } \\
\text { Did that motivate you to study harder since your } \\
\text { instructor knows you? }\end{array}$ & 7 & 25 & 2 & 2 \\
\hline & Total & 55 & 145 & 8 & 7 \\
\hline
\end{tabular}

*) One answer was excluded since the answer was that he/she has not been asked to come forward and working on an exercise on the board.

We calculate the percentage of students' positive response using formula number (1). Since the wording of each questions were asking about the positive impact of the teaching strategies, then we can calculate the positive responses as the total number of "Very much" and "Yes". Category of "Fair" contains fifty-fifty chance of positive and negative impression, so that for simplicity is not calculated in the numerator. Therefore, the percentage of total positive response of our active class strategies is:

$\frac{\text { Total number of "Very much" }+ \text { Total Number of "Yes" }}{\text { Total Number of all Categories }} \times 100 \%$ 
Yielding the percentage of student's positive response of:

$$
\frac{55+145}{55+145+8+7} \quad \times 100 \%=\underline{\mathbf{9 3 . 0 2} \%}
$$

In details, from Table 1, we can see the facts that:

- Our active class design where we divide class into small groups and let students work on exercises and solve problems together with their group members is indeed beneficial for students. This can be seen in question number 1 where we gain $100 \%$ of students' positive response. No student responder answered "Fair" or "No".

- Answers for question number 3 shows that 34 out of 35 students (97\%) give positive response. It means that our strategy to ask students to represent their group to work on an exercise on the board, or to present the result of their group in front of the class has motivated students to understand the teaching material.

- No student disagrees that personal approach in teaching is raising students understanding of the teaching materials. It is shown in answers from question number 5 where $97.2 \%$ students, i.e., 21 students agree and 14 students are very agree that when the instructor come and visit the group and explain the part of the teaching material that has not been cleared to students, can increase students' understanding of teaching materials.

- Motivation to be active in class by giving bonus points gains $86.1 \%$ of students' interest, while motivation using positive words wins $88.89 \%$. Similar to it, $88.89 \%$ students agree that the fact that instructor knows students name is important to motivate students to study harder.

- Knowing students' name is important to motivate students to study harder since their instructor knows them personally (Answers of the question number 4). Positive answer was 32 out of 36 answers $(88.89 \%)$. Only two students think that the fact that their instructor knows their name does not impact their motivation. This means that it is indeed that personal approach is still needed in motivating students to study.

Table 2. Categories of students' answers

\begin{tabular}{|l|l|l|}
\hline \multicolumn{1}{|c|}{ Category } & If the answer contains these words & \multicolumn{1}{|c|}{ Example of the phrase } \\
\hline "Very much" & "Sangat", "Sekali", "Amat" & $\begin{array}{l}\text { "Iya betul sekali..." } \\
\text { (Yes, very correct), } \\
\text { "Sangat membantu... } \\
\text { (Yes, very helpful) }\end{array}$ \\
\hline "Yes" & "Iya", "Tentu" & $\begin{array}{l}\text { "Iya pasti." } \\
\text { (Yes, sure) } \\
\text { "Tentu saja } \\
\text { (Of course) }\end{array}$ \\
\hline "Fair" & "Lumayan" & $\begin{array}{l}\text { "Lumayan membantu." } \\
\text { (Fairly helpful) }\end{array}$ \\
\hline "No" & $\begin{array}{l}\text { "Tidak" } \\
\text { (No) }\end{array}$ \\
& "Tidak", "Tidakjuga" & $\begin{array}{l}\text { "Tidak juga. } \\
\text { (Not really) }\end{array}$ \\
\hline
\end{tabular}




\section{Conclusion}

Aligned with other studies reviewed in section 2, our class design that lead to active learning is indeed has positive impact to students for understanding the teaching material. Over $93 \%$ of students' give positive response about our active learning class environment. Small group discussions make active learning more effective since there are knowledge transfers between group members. Supervision of the instructor is still needed to the groups' activities to keep students to be on the right track, i.e., constructing the right knowledge. Personal approach can increase motivation of students to be active in class and to study harder. We conclude that our active learning class design can increase students understanding of the teaching material, and hence, students' grades.

\section{References}

[1] A.Srinath, "Active Learning Strategies:sspe An Illustrative Approach to Bring out Better Learning Outcomes from Science, Technology, Engineering and Mathematics (STEM) Students "isE-P., iJET - Volume 9, Issue 9: "Blended Learning", 2014.

[2] Dahlgren, M.A., and Dahlgren,, L.O. "Portraits of PBL: Students' experiences of the characteristics of problem-based learning in physiotherapy, psychology", $\quad$ Instructional science, $\quad(30), \quad 2, \quad 111-127$. http://dx.doi.org/10.1023/A:1014819418051, 2002.

[3] Freeman, S., Eddy, S.L., McDonough, M., Smith, M.K., Okoroafor, N., Jordt, H., Wenderoth, M.P., (2014). Active learning increases students' performance in science, engineering, and mathematics. Proceedings of the National Academy of Sciences of the United States of America June 10, 2014111 (23) 8410-8415, 2014

[4] Gurung, R.A.R. and Voelker D.J., (Editors), "Big Picture Pedagogy: Finding Interdisciplinary Solutions to Common Learning Problems, New Directions for Teaching and Learning", Number 151. Fall 2017. Josse-Bass, A Wiley Brand, 2017

[5] Komarraju, M. \& Nadler, D. (2013). Self Efficacy and Academic Achievement: Why do implicit beliefs, goals, and effort regulation matter? Learning and Individual Differences 25, 67-72, 2013.

[6] Owens, M.T., and Tanner K.D, "Teaching as Brain Changing: Exploring Connections between Neuroscience and Innovative Teaching. Approaches to Biology Teaching and Learning." CBE Life Sciences Education 16: fe2, summer, 2017.

[7] Woolfson, L.M, "Educational Psychology, The impact of psychological research on education", Pearson Education Limited. ISBN: 978-0-273-72919-8, 2011

[8] Susanna Hartikainen, Heta Rintala, Laura Pylväs, and Petri Nokelainen, "The Concept of Active Learning and the Measurement of Learning Outcomes: A Review of Research in Engineering Higher Education”, Educ. Sci. 9, 276; doi:10.3390/educsci9040276., 2019

[9] Andreas Schäfer, Jan Holz, Thiemo Leonhardt, Ulrik Schroeder, Philipp Brauner \& Martina Ziefle "From boring to scoring - a collaborative serious game for learning and practicing mathematical logic for computer science education", Computer Science Education, 23:2, 87111, DOI: 10.1080/08993408.2013.778040 , 2013

[10] Natalie Wilde and Anne Hsu, "The influence of general self-efficacy on the interpretation of vicarious experience information within online learning", International Journal of Educational Technology in Higher Education 16:26, 2019

[11] Linda Zientek, Jennifer Dorsey, Nancy Stano, Forrest C. Lane, "An investigation of selfefficacy of students enrolled in a mathematics pathway course", Journal of Applied Research in Higher Education is Pol. 11 No. 3, 2019

[12] Bandura, A. "Self-Efficacy: The Exercise of Control", W.H. Freeman and Company, New York, NY. , 1997

[13] Ozkal, N. "Relationships between self-efficacy beliefs, engagement and academic performance in math lessons. Cypriot Journal of Educational Science". 14(2), 190-200, 2019 
Vol. 3, No. 1, August 2020

[14] Bandura, A. (1994). Self-efficacy. In V. S. Ramachaudran (Ed.), Encyclopedia of human behavior (Vol. 4, pp. 71-81). New York: Academic Press. (Reprinted in H. Friedman [Ed.], Encyclopedia of mental health. San Diego: Academic Press, 1998).

[15] Ayllon S, Alsina A, Colomer J, “Teachers' involvement and students' self-efficacy: Keys to achievement in higher education. PLoS ONE 14(5): e0216865. https://doi.org/10.1371/ journal.pone.0216865, 2019

[16] Turner, J.C. \& Reynolds, Katherine. "Self-categorization theory. Handbook of theories in social psychology", doi: 10.4135/9781446249222.n46., 2012

[17] Katelyn M. Cooper, Brian Haney, Anna Krieg, and Sara E. Brownel, "What's in a Name? The Importance of Students Perceiving That an Instructor Knows Their Names in a HighEnrollment Biology Classroom”, CBE—Life Sciences Education • 16:ar8, 1-13, Spring 2017.

[18] Kimberly D. Tanner, "Structure Matters: Twenty-One Teaching Strategies to Promote Student Engagement and Cultivate Classroom Equity", CBE-Life Sciences Education Vol. 12, 322331, Fall 2013. 